\title{
Early detection of acute kidney injury in the perioperative period of liver transplant with neutrophil gelatinase-associated lipocalin
}

Camila Lima ${ }^{1,2^{*}}$ (D), Luciana Bertocco de Paiva Haddad ${ }^{3,4}$, Patrícia Donado Vaz de Melo ${ }^{5}$, Luiz Marcelo Malbouisson ${ }^{6}$, Lilian Pires Freitas do Carmo', Luiz Augusto Carneiro D'Albuquerque ${ }^{4}$ and Etienne Macedo ${ }^{1,7}$

\begin{abstract}
Background: Acute kidney injury (AKI) is a common complication in patients undergoing liver transplant (LT) and is associated with high morbidity and mortality. We aim to evaluate the pattern of urine and plasma neutrophil gelatinase-associated lipocalin (NGAL) elevation during the perioperative period of LT and to assess it as a prognostic marker for AKI progression, need for dialysis and mortality.

Methods: We assessed NGAL levels before induction of anesthesia, after portal reperfusion and at 6, 18, 24, and 48 $\mathrm{h}$ after surgery. Patients were monitored daily during the first week after LT.

Results: Of 100 enrolled patients undergoing liver transplant, 59 developed severe AKI based on the KDIGO serum creatinine ( $\mathrm{s} C \mathrm{r}$ ) criterion; 34 were dialysed, and 21 died within 60 days after LT. Applying a cut-off value of $136 \mathrm{ng} /$ $\mathrm{ml}$, UNGAL values $6 \mathrm{~h}$ after surgery was a good predictor of AKI development within 7 days after surgery, having a positive predictive value (PPV) of $80 \%$ with an AUC of 0.76 (95\% Cl 0.67-0.86). PNGAL at $18 \mathrm{~h}$ after LT was also a good predictor of AKI in the first week, having a PPV of $81 \%$ and AUC of 0.74 ( $95 \% \mathrm{Cl} 0.60-0.88)$. Based on PNGAL and UNGAL cut-off criteria levels, time to AKI diagnosis was 28 and $23 \mathrm{~h}$ earlier than by $\mathrm{s} C \mathrm{C}$, respectively. The best times to assess the need for dialysis were $18 \mathrm{~h}$ after LT by PNGAL and $06 \mathrm{~h}$ after LT by UNGAL.

Conclusion: In conclusion, the plasma and urine NGAL elevation pattern in the perioperative period of the liver transplant can predict AKI diagnosis earlier. UNGAL was an early independent predictor of AKI development and need for dialysis. Further studies are needed to assess whether the clinical use of biomarkers can improve patient outcomes.
\end{abstract}

Trial registration: Registered at Clinical Trials (clinicaltrials.gov) in March 24th, 2014 by title "Acute Kidney Injury Biomarkers: Diagnosis and Application in Pre-operative Period of Liver Transplantation (AKIB)" and identifier NCT02095431, retrospectively registered.

Keywords: Acute kidney injury, Biomarkers, Liver transplant, Neutrophil gelatinase-associated lipocalin, Renal dialysis

\footnotetext{
* Correspondence: camilaxlima@gmail.com

'Department of Internal Medicine, Nephrology Division, University of Sao

Paulo, Present Address: 419 Av. Dr Enéas de Carvalho Aguiar, third floor room 340, 05403-000, Cerqueira Cesar, São Paulo, Brazil

${ }^{2}$ Department of Medical Surgical Nursing, University of Sao Paulo Nursing

School, Sao Paulo, Brazil

Full list of author information is available at the end of the article
}

(c) The Author(s). 2019 Open Access This article is distributed under the terms of the Creative Commons Attribution 4.0 International License (http://creativecommons.org/licenses/by/4.0/), which permits unrestricted use, distribution, and reproduction in any medium, provided you give appropriate credit to the original author(s) and the source, provide a link to the Creative Commons license, and indicate if changes were made. The Creative Commons Public Domain Dedication waiver (http://creativecommons.org/publicdomain/zero/1.0/) applies to the data made available in this article, unless otherwise stated. 


\section{Background}

Acute kidney injury (AKI) is a common complication in patients undergoing liver transplant (LT) [1]. Recent studies have shown that even mild or transient post-LT AKI is associated with prolonged intensive care or hospital stay, decreased organ survival, and increased allcause mortality [1-3].

The etiology of AKI after LT is multifactorial and includes recipient, graft, perioperative, and postoperative risk factors [4]. Pre-operative kidney dysfunction is often a reflection of the degree of liver dysfunction and an important risk factor for post-LT AKI [5, 6]. Perioperative intravascular depletion, severity of post-reperfusion syndrome, hemodynamic instability and nephrotoxic medications further increase the risk of AKI development $[4,7]$.

Despite improvements in organ preservation, surgery techniques, and immunosuppression protocols, the incidence of AKI after LT continues to be high, reaching $50 \%$ in some studies $[8,3]$. In the first year after liver transplant, the development of AKI in the post-operative period is a major factor impacting organ survival $[9,10]$. Several studies have shown reduced organ survival, especially when renal replacement therapy (RRT) is needed after transplant [11]. Development of chronic kidney disease (CKD) and/or accelerated progression to end-stage renal disease (ESRD) are also potential consequences of AKI after liver transplant $[9,12]$. Progression to CKD occurs in $18.1 \%$ of patients after LT, and $4.8 \%$ of patients progress to ESRD in five years [13, 14].

Challenges in risk assessment and early management in patients developing AKI significantly contribute to worse prognoses in these patients. The limitations of serum creatinine $(\mathrm{sCr})$ as a diagnostic marker for acute kidney injury are more evident in patients with liver disease due to malnutrition and decreased muscle mass [15-17]. Therefore, patients in the perioperative period of LT may benefit from more sensitive and specific biomarkers of kidney injury [18]. These biomarkers should be able to allow for early identification of AKI, ideally providing information about the etiology and helping to distinguish functional changes from structural damage.

Several biomarkers of early kidney injury have been identified and, although these novel AKI biomarkers have primarily been assessed in general intensive-care populations [19-21], they have also been applied in liver-transplant recipients [22-25]. NGAL is a small, secreted polypeptide that is upregulated in response to tubular injury and rapidly detectable in plasma and urine. Within $24 \mathrm{~h}$ after liver transplantation, plasma NGAL is a better predictor of AKI than serum creatinine $[22-24,26]$. Additional studies with small numbers of patients have suggested that plasma NGAL can detect post-LT AKI as early as $1-2 \mathrm{~h}$ after reperfusion $[22,26]$. Few studies have evaluated NGAL as a predictor of need for RRT and mortality in the perioperative period of LT.

In this study, we aimed to determine whether the pattern of NGAL urinary and plasma elevation in the perioperative period of LT could be a prognostic tool for determining AKI severity, progression, need for RRT and mortality.

\section{Methods}

The University of Sao Paulo Ethics Committee approved the study under protocol numberCAAE:06636513.4.0000.0068. All clinical and research activities being reported are consistent with the Principles of the Declaration of Istanbul and with the Declaration of Helsinki. The protocol is registered among the clinical trials available at https://clinicaltrials.gov, with identifier NCT02095431. Patients were enrolled into the study after written informed consent was obtained from all participants as per the guidelines of the Institution's Ethics Committee.

\section{Patients}

During a 24-month period from June 2013 to June 2015, a total of 189 liver transplants were performed and 139 recipients were eligible for our study (Fig. 1). During the study period, all recipients older than 18 years old were screened. Patients were enrolled after written voluntary informed consent was obtained as per the guidelines of the Institution's Ethics Committee. Exclusion criteria included pre-operative need for dialysis, combined transplant, chronic kidney disease stage 5, and previous kidney or liver transplant.

Patients were classified according to the etiology of endstage liver disease (ESLD): hepatitis-B or -C cirrhosis, alcoholic cirrhosis, cryptogenic cirrhosis, acute hepatitis and miscellaneous causes. The miscellaneous group included patients with non-alcoholic steatohepatitis (NASH), autoimmune hepatitis, hemochromatosis, Budd-Chiari syndrome, biliary atresia, Wilson's disease, primary sclerosing cholangitis, polycystic disease, biliary cirrhosis, and hepatocellular carcinoma.

The standard triple-drug immunosuppression regimen of tacrolimus with mycophenolate mofetil and steroids was used to prevent allograft rejection.

\section{Data collection}

We recorded baseline kidney function and comorbid history from electronic medical records (EMRs). The following perioperative variables were included: main patient characteristics, intra-operative data, clinical follow-up in the first week after LT, need-for-RRT data, and outcomes.

The functional Model for End-stage Liver Disease (MELD) was calculated on the basis of serum bilirubin, 
Not included (38):

Delayed communication between transplant

coordination and research team : 16

Research lab closed : 13

No surrogate to signed consent: 6

Refused to participate in the study : 3

Patients undergoing LT June

2013 to June 2015

189

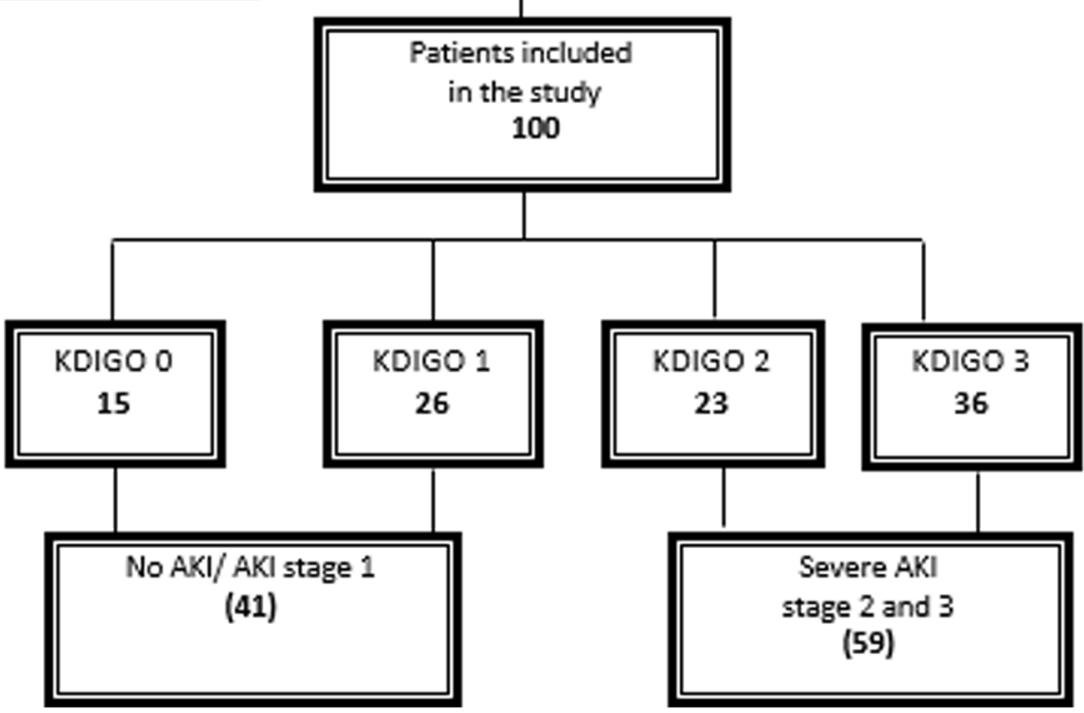

Fig. 1 Flowchart of enrolled patients

international normalised ratio (INR) and serum creatinine, by the following formula:

$$
\begin{aligned}
\text { MELD score }= & 0.957 \times \operatorname{In}(\text { creatinine } \mathrm{mg} / \mathrm{dl}) \\
& +0.378 \times \operatorname{In}(\text { bilirubin } \mathrm{mg} / \mathrm{dl}) \\
& +1.120 \times \operatorname{In}(\text { INR })+0.643 \times 10
\end{aligned}
$$

The liver transplant (LT) MELD was the sum of the functional MELD and the point score in special situations of transplant priority [27].

Blood and urine samples were collected simultaneously in the perioperative period of LT before induction of anesthesia, after portal reperfusion and at 6, 18, 24 and $48 \mathrm{~h}$ after surgery. We recorded vital signs, process of care, and lab results daily for 7 days after LT. Outcomes including maximum AKI severity stage, need for RRT and mortality were assessed in the intensive care unit (ICU), on hospital discharge and 60 days after enrolment.

\section{NGAL assessment}

Blood samples were collected from central venous catheters or arterial lines, and urine through indwelling catheters. After collection, samples were immediately centrifuged - blood samples at 3000 rotations per minute (rpm) for $15 \mathrm{~min}$ and urine at $1000 \mathrm{rpm}$ for $10 \mathrm{~min}-$ and stored at $-80^{\circ} \mathrm{C}$ prior to analysis.

Quantitative NGAL levels were measured using particle-enhanced turbidimetric immunoassay (PETIA) for NGAL determination, according to the manufacturer's instructions. The test uses an immunoturbidimetric method, in which polystyrene particles are coated with anti-NGAL antibody and, upon contact with the analyte in the sample, this results in turbidity 
proportional to the concentration of NGAL. Tests were performed in Labmax 560 equipment. Perioperative serum creatinine from the same samples as the NGAL measurement was analysed by chemiluminescence. All other serum creatinine values recorded from medical records were analysed by Jaffe method in the hospital's central laboratory.

\section{Clinical outcomes}

The primary outcome was AKI development during the first week of LT. Baseline renal function was defined as the lowest value in the prior three months and was used to assess renal recovery. AKI diagnosis was based on Kidney Disease: Improving Global Outcomes (KDIGO) [28]. For the reference serum creatinine value, we used the lowest value within 7 days before liver transplantation, and this value was used to determine AKI diagnosis. AKI stage was defined, according to KDIGO, as follows: stage 1 (1.5-1.9 times reference $\mathrm{sCr}$ or an increase of $\geq 0.3 \mathrm{mg} / \mathrm{dl}$ within $48 \mathrm{~h})$, stage $2(2.0-2.9$ times reference sCr), stage 3 (3.0 times reference $\mathrm{sCr}$ or an increase of $>4.0 \mathrm{mg} / \mathrm{dl}$ ). Patients with no AKI or stage 1 AKI were categorized as the no-AKI/mild-AKI group, whereas patients meeting the criteria for stage 2 or 3 AKI seven days after LT were identified as severe AKI. Secondary outcomes included need for RRT and mortality, assessed in the intensive care unit (ICU), on hospital discharge and at 60 days after enrolment.

\section{Statistical analysis}

Continuous variables are presented as mean \pm standard deviation (SD) or median (25th-75th percentiles) and were compared using one-way ANOVA or Kruskal-Wallis testing according to the Gaussian distribution. Categorical variables are presented as absolute numbers and percentages and were compared by the Chi-square test. $P$ values were two tailed, and $P<0.05$ was considered significant. Conventional receiver operating characteristic (ROC) curves were generated, and the area under the curve (AUC) was used to assess the ability of continuous variables to distinguish the categorical state: AKI development, need for dialysis and non-survival. The optimal cutoffs were determined by the best point of sensitivity versus specificity of the AUC (Youden index).

We compared time to AKI diagnosis based on biomarkers versus creatinine analyzed by chemiluminescence in the same sample collection. Time to diagnose based on $\mathrm{sCr}$ criterion was assessed by KDIGO stage 1 definition and biomarkers were determined by the cutoff value determined for plasma NGAL (PNGAL) and urine NGAL (UNGAL).

The perioperative covariates were tested in univariate analysis for their impact on AKI development, need for dialysis and non-survival. Factors associated with the outcomes at $P<0.01$ were used to construct a multivariable model, in which the impact of each comorbidity or covariate was adjusted. In each model, UNGAL or PNGAL was included as a covariate. The SPSS (Statistical Package for Social Sciences) version 20 (Chicago, Illinois) software was used for the statistical analysis.

\section{Results}

\section{Patient characteristics}

Of 189 adult patients undergoing LT within the study period, 138 were eligible, and 100 were enrolled in the study. Figure 1 shows reasons for non-enrolment. Patients' demographic and clinical characteristics are shown in Table 1. Baseline and reference serum creatinine values were similar in severe-AKI and no-AKI/mild-AKI groups. The estimated glomerular filtration rate (eGFR), based on the CKD Epidemiology Collaboration (EPI), corresponded to the baseline $\mathrm{sCr}$, was similar within the groups. eGFR based on reference $\mathrm{sCr}$ was lower in the severe-AKI group.

\section{AKI development}

Based on the baseline ambulatory values, 34 patients were classified with acute kidney disease before surgery, of whom $23(67.6 \%)$ were KDIGO stage 1. Based on the reference $\mathrm{sCr}, 85$ patients developed AKI (stage 1/2/3). Patients developing no AKI or stage 1 AKI within the first 7 days of LT were summarized as the no-AKI/mild-AKI group 41 (41\%), whereas patients meeting the criteria for stage 2 or 3 AKI group within the first 7 days of LT were summarized as the severe-AKI 59 (59\%) (Fig. 1).

\section{Risk factors for AKI}

Patients developing severe AKI were younger, had a higher functional MELD before surgery and higher Sequential-Organ--Failure (SOFA) scores on ICU admission (Table 1). Duration of anesthesia, hepatectomy and warm ischemia time were significantly prolonged in severe-AKI patients. In the first day after LT, urine output was significantly lower in the severe-AKI group and the cumulative fluid balance was higher, with a difference of approximately $600 \mathrm{ml}$ between groups $(P=$ $0.008)$.

\section{Performance of NGAL for diagnosis of AKI in the perioperative LT period}

Six hours after LT, severe-AKI patients had 10.6-fold higher UNGAL levels than those in the no-AKI/mildAKI group, followed by a sustained significant difference for $24 \mathrm{~h}$ after surgery (Fig. 2). UNGAL achieved the best performance for predicting severe AKI at six hours after LT, with an AUC of 0.76 (95\% CI $0.67-$ 0.86). The best cut-off value was $136 \mathrm{ng} / \mathrm{ml}$, with a 
Table 1 Clinical characteristics and outcomes in patients with and without moderate to severe AKI progression

\begin{tabular}{|c|c|c|c|c|}
\hline PATIENT CHARACTERISTICS AND OUTCOMES & Total & No AKI/mild AKI & Severe AKI & $p$ \\
\hline $\mathrm{N}$ & $100(100 \%)$ & $41(41 \%)$ & $59(59 \%)$ & $<0.0001$ \\
\hline \multicolumn{5}{|l|}{ Baseline Characteristics } \\
\hline Age & $58(12)$ & $57(12)$ & $53(12)$ & 0.01 \\
\hline Gender (Male) & $64(64 \%)$ & $27(42 \%)$ & $37(58 \%)$ & 0.75 \\
\hline BMI & $26(4)$ & $26(4)$ & $26.5(5)$ & 0.65 \\
\hline Non caucasian & $14(14 \%)$ & $05(36 \%)$ & $09(64 \%)$ & 0.11 \\
\hline MELD functional & $15(11-19)$ & $14(10-17)$ & $16(12-22)$ & 0.01 \\
\hline MELD LT & $29(29-29)$ & $29(29-29)$ & $29(29-32)$ & 0.96 \\
\hline \multicolumn{5}{|l|}{ Liver Disease } \\
\hline hepatitis C & $46(46 \%)$ & $17(37 \%)$ & $29(63 \%)$ & 0.44 \\
\hline Alcoholic cirrhosis & $13(13 \%)$ & $06(46 \%)$ & 07(54\%) & 0.68 \\
\hline Cryptogenic cirrhosis & $12(12 \%)$ & $05(42 \%)$ & $07(58 \%)$ & 0.96 \\
\hline acute hepatitis & $06(06 \%)$ & 03(50\%) & 03(50\%) & 0.64 \\
\hline hepatitis B & $04(04 \%)$ & $02(50 \%)$ & $02(50 \%)$ & 0.70 \\
\hline Other & 19 (19\%) & $08(42 \%)$ & $11(57 \%)$ & 0.91 \\
\hline \multicolumn{5}{|l|}{ Comorbidities } \\
\hline Hypertension & 33(33\%) & $12(36 \%)$ & $21(64 \%)$ & 0.43 \\
\hline Diabetes mellitus & $28(28 \%)$ & $14(50 \%)$ & $14(50 \%)$ & 0.26 \\
\hline \multicolumn{5}{|l|}{ Kidney function } \\
\hline baseline $\mathrm{s} C r$ & $0.77(0.63-0.99)$ & $0.77(0.62-0.98)$ & $0.77(0.65-1.00)$ & 0.87 \\
\hline reference $\mathrm{sCr}$ & $0.78(0.62-1.02)$ & $0.77(0.64-1.02)$ & $0.80(0.61-1.00)$ & 0.96 \\
\hline Estimated GFR (CKD-EPI) by Scr ref. & 78.65 (52-99) & $93.50(64-105)$ & $69.40(45-98)$ & 0.013 \\
\hline Estimated GFR (CKD-EPI) by Scr base & $99.65(74-110)$ & $99.25(75-108)$ & $108.52(69-117)$ & 0.67 \\
\hline Urine output first day after LT & $475(45)$ & $608(79)$ & $383(49)$ & 0.01 \\
\hline Fluid balance first day after $\mathrm{LT}$ & + 1535 (+ 500-2315) & $+1010(+367-1782)$ & $+1655(+890-2447)$ & 0.008 \\
\hline \multicolumn{5}{|l|}{ Severity score indices } \\
\hline SAPS & $64(60-72)$ & $64(11)$ & $69(15)$ & 0.68 \\
\hline SOFA & $13(11-15)$ & $12(10-13)$ & $14(12-16)$ & 0.001 \\
\hline \multicolumn{5}{|l|}{ process of care } \\
\hline Anesthesia time & 09:56 (01:59) & 09:08 (01:33) & 10:32 (02:04) & $<0.0001$ \\
\hline HEPATECTOMY TIME (HH:MM) & 03:11 (00:54) & 02:54 (00:46) & 03:27 (00:57) & 0.003 \\
\hline warm ischemia time (HH:MM) & $00: 42(1: 11)$ & $00: 41(1: 21)$ & $00: 43(1: 52)$ & $>0.0001$ \\
\hline cold ischemia time (HH:MM) & 06:04 (01:55) & 05:49 (02:06) & 06:14 (01:46) & 0.73 \\
\hline Red blood cELLS (unit) & $2.39(2.8)$ & $1.45(2.57)$ & $3(2.9)$ & 0.002 \\
\hline \multicolumn{5}{|l|}{ outcomes } \\
\hline Time with vasoactive drugs (days) & $2(1.78)$ & $1(1.18)$ & $2(2)$ & 0.01 \\
\hline Days of Mechanical ventilation & $2(1.82)$ & $1(0.57)$ & $3(2)$ & $<0.0001$ \\
\hline Lenght of ICU stay (days) & $9.81(13)$ & $5.59(6.3)$ & $12.75(2)$ & 0.003 \\
\hline Lenght of hospital stay (days) & $29(28)$ & $19.17(14.6)$ & $36(4.2)$ & $<0.0001$ \\
\hline Need for Retransplant & $11(11 \%)$ & $01(09 \%)$ & $10(91 \%)$ & 0.02 \\
\hline Need for RRT & $36(36 \%)$ & $04(10.5 \%)$ & 34 (89.5\%) & $<0.0001$ \\
\hline 60 day Mortality & $21(21 \%)$ & $03(14.3 \%)$ & $18(85.7 \%)$ & 0.004 \\
\hline
\end{tabular}

Data are expressed as $n(\%)$, mean $( \pm)$, median and percentile (25-75) according to their distribution. Time of anesthesia expressed as hours: minutes. BMI (body mass index), MELD (model for end-stage liver disease), LT (liver transplant), ICU (intensive unit care), SAPS (Simplified Acute Physiology Score), SOFA (Sequential Organ Failure Assessment), RRT (renal replacement therapy), GFR (glomerular filtration rate), CKD- Epidemiology Collaboration 

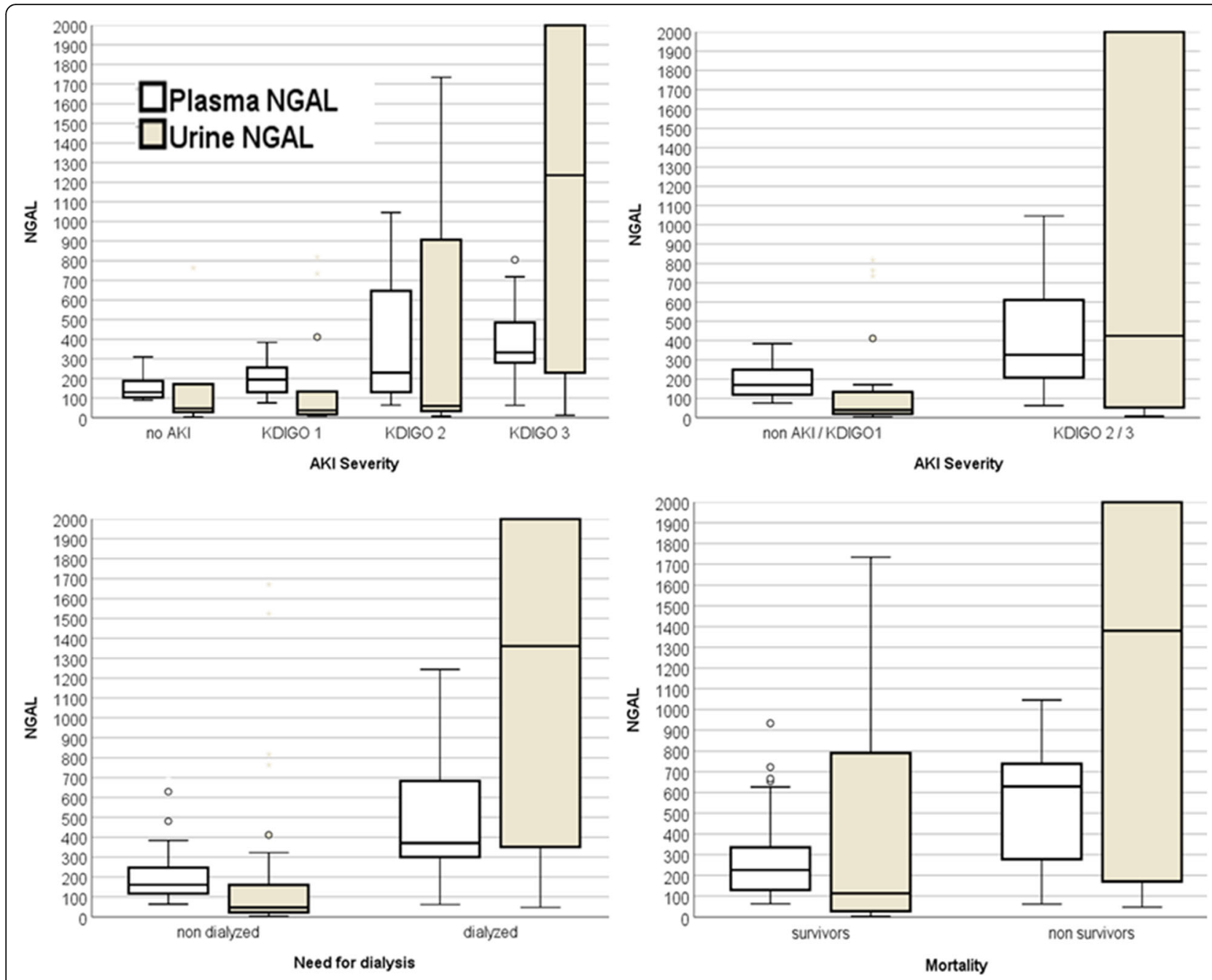

Fig. 2 Median of the PNGAL eighteen hours after LT and UNGAL six hours after LT and outcome groups

sensitivity of $68 \%$, specificity of $76 \%$, and positive predictive value (PPV) of $80 \%$.

Median PNGAL was higher in the severe-AKI versus no-AKI/mild-AKI group, reaching statistical significance six hours after LT; severe AKI $265 \mathrm{ng} / \mathrm{ml}$ vs. no-AKI/ mild-AKI $138 \mathrm{ng} / \mathrm{ml}(P=0.01)$. Eighteen hours after LT, PNGAL levels were approximately 2-fold higher in severe-AKI patients; median $326 \mathrm{ng} / \mathrm{ml}$ in AKI vs. 170 $\mathrm{ng} / \mathrm{ml}$ in no-AKI /mild-AKI (Fig. 2). The best cut-off value for predicting AKI was $198 \mathrm{ng} / \mathrm{ml}$, with a sensitivity of $87 \%$, specificity $71 \%$ and PPV of $81 \%$ (Table 2 ).

\section{Early diagnosis of AKI by biomarkers versus serum creatinine}

We evaluated time to AKI diagnosis based on NGAL cut-off values and sCr KDIGO criterion in the first $48 \mathrm{~h}$ after transplant. For this analysis, we used $\mathrm{sCr}$ measured by chemiluminescence in the same samples as the biomarkers. AKI diagnosis was reached in 72 patients by sCr, in 83 by PNGAL and in 65 by UNGAL levels. The median time based on PNGAL was $28 \mathrm{~h}$ earlier than $\mathrm{sCr}$ (Fig. 3), and UNGAL reached diagnosis $23 \mathrm{~h}$ earlier than sCr (Fig. 3).

\section{Performance of NGAL in determining the need for RRT in} the perioperative LT period

Thirty-eight patients were dialysed during hospitalization, 34 in the first week after LT. The best performance of PNGAL in predicting the need for RRT was at $18 \mathrm{~h}$, with an AUC of 0.84 (95\% CI $0.74-0.93$ ), sensitivity of $87 \%$ and a specificity of $83 \%$. Using the cut-off value of $286 \mathrm{ng} / \mathrm{ml}$, UNGAL was able to predict the need for RRT with the best performance at $6 \mathrm{~h}$ after LT, a cut-off of $210 \mathrm{ng} / \mathrm{ml}$ determining an AUC 0.85 (95\% CI 0.77-0.93), with a sensitivity of $86 \%$ and the specificity of $80 \%$ (Table 2, Fig. 2). 
Table 2 Progression of PNGAL and UNGAL in AKI, max KDIGO stage, need for RRT and mortality groups

\begin{tabular}{|c|c|c|c|c|c|c|}
\hline \multicolumn{7}{|l|}{ PNGAL values } \\
\hline & Pre-op. (100) & Intra-op. (95) & $6 \mathrm{~h}(90)$ & 18 h (87) & $24 \mathrm{~h}(86)$ & 48 h (74) \\
\hline no AKI / mild AKI & $\begin{array}{l}172 \\
(102-331)\end{array}$ & $\begin{array}{l}196 \\
(117-310)\end{array}$ & $\begin{array}{l}138 \\
(93-282)\end{array}$ & $\begin{array}{l}170 \\
(117-252)\end{array}$ & $\begin{array}{l}156 \\
(113-243)\end{array}$ & $\begin{array}{l}116 \\
(89-221)\end{array}$ \\
\hline severe AKI & $\begin{array}{l}185 \\
(114-287)\end{array}$ & $\begin{array}{l}232 \\
(158-364)\end{array}$ & $\begin{array}{l}265 \\
(177-429)\end{array}$ & $\begin{array}{l}326 \\
(180-616)\end{array}$ & $\begin{array}{l}356 \\
(215-666)\end{array}$ & $\begin{array}{l}369 \\
(235-535)\end{array}$ \\
\hline$P$ & 0.82 & 0.50 & 0.047 & 0.004 & $<0.0001$ & $<0.0001$ \\
\hline no-RRT & 166 (79-270) & $\begin{array}{l}192 \\
(127-323)\end{array}$ & $\begin{array}{l}183 \\
(86-281)\end{array}$ & $\begin{array}{l}168 \\
(120-249)\end{array}$ & $\begin{array}{l}173 \\
(122-286)\end{array}$ & $134(91-248)$ \\
\hline need RRT & $204(115-465)$ & $\begin{array}{l}318 \\
(204-407)\end{array}$ & $\begin{array}{l}341 \\
(242-510)\end{array}$ & $\begin{array}{l}459 \\
(306-749)\end{array}$ & $\begin{array}{l}608 \\
(333-749)\end{array}$ & $481(292-689)$ \\
\hline$P$ & 0.27 & 0.015 & $<0.0001$ & $<0.0001$ & $<0.0001$ & $<0.0001$ \\
\hline survivors & $\begin{array}{l}197.49 \\
(117-326)\end{array}$ & $\begin{array}{l}213.43 \\
(129-337)\end{array}$ & $\begin{array}{l}199.73 \\
(110-343)\end{array}$ & $\begin{array}{l}226.06 \\
(129-335)\end{array}$ & $\begin{array}{l}228.09 \\
(134-368)\end{array}$ & $\begin{array}{l}116.11 \\
(117-326)\end{array}$ \\
\hline non-survivors & $\begin{array}{l}165 \\
(98-249)\end{array}$ & $\begin{array}{l}309 \\
(105-389)\end{array}$ & $\begin{array}{l}279.5 \\
(183-529)\end{array}$ & $\begin{array}{l}629.01 \\
(256-759)\end{array}$ & $\begin{array}{l}619.10 \\
(301-689)\end{array}$ & $\begin{array}{l}503.50 \\
(281-697)\end{array}$ \\
\hline$P$ & 0.51 & 0.64 & 0.22 & 0.001 & 0.001 & 0.001 \\
\hline \multicolumn{7}{|l|}{ UNGAL values } \\
\hline & Pre-op. (97) & Intra-op. (84) & 6 h (87) & $18 \mathrm{~h} \mathrm{(75)}$ & $24 \mathrm{~h}(71)$ & 48 h (62) \\
\hline no AKI / mild AKI & $\begin{array}{l}27 \\
(17-244)\end{array}$ & $\begin{array}{l}35 \\
(16-402)\end{array}$ & $\begin{array}{l}40 \\
(18-143)\end{array}$ & $\begin{array}{l}62 \\
(32-380)\end{array}$ & $\begin{array}{l}72 \\
(26-248)\end{array}$ & $\begin{array}{l}147 \\
(44-338)\end{array}$ \\
\hline severe AKI & $\begin{array}{l}90 \\
(23-254)\end{array}$ & $\begin{array}{l}119 \\
(26-1669)\end{array}$ & $\begin{array}{l}424 \\
(51-2802)\end{array}$ & $\begin{array}{l}312 \\
(55-1542)\end{array}$ & $\begin{array}{l}329 \\
(85-1290)\end{array}$ & $\begin{array}{l}247 \\
(50-1820)\end{array}$ \\
\hline$P$ & 0.90 & 0.008 & $<0.0001$ & 0.006 & 0.004 & 0.23 \\
\hline no-RRT & $27(16-167)$ & 26(15-98) & $70(27-160)$ & $78(35-262)$ & 110(28-318) & $70(18-317)$ \\
\hline need RRT & $\begin{array}{l}179 \\
(34-513)\end{array}$ & $\begin{array}{l}602 \\
(34-2912)\end{array}$ & $1361(603-2131)$ & $\begin{array}{l}855 \\
(335-1979)\end{array}$ & $\begin{array}{l}660 \\
(195-3109)\end{array}$ & $\begin{array}{l}667 \\
(102-1650)\end{array}$ \\
\hline$P$ & 0.001 & $<0.0001$ & $<0.0001$ & $<0.0001$ & 0.001 & 0.002 \\
\hline survivors & $\begin{array}{l}33 \\
(15-372)\end{array}$ & $\begin{array}{l}47.10 \\
(20-522)\end{array}$ & $\begin{array}{l}113.10 \\
(28-817)\end{array}$ & $\begin{array}{l}131.20 \\
(37-818)\end{array}$ & $\begin{array}{l}147.80 \\
(42-546)\end{array}$ & $\begin{array}{l}214.80 \\
(95-1608)\end{array}$ \\
\hline non-survivors & $\begin{array}{l}220.40 \\
(49-549)\end{array}$ & $\begin{array}{l}181.71 \\
(42-3046)\end{array}$ & $\begin{array}{l}1235.70 \\
(77-3806)\end{array}$ & $\begin{array}{l}309.69 \\
(138-3718)\end{array}$ & $\begin{array}{l}332.71 \\
(109-3861)\end{array}$ & $\begin{array}{l}3291 \\
(340-3950)\end{array}$ \\
\hline$P$ & 0.02 & 0.11 & 0.005 & 0.06 & 0.09 & 0.0004 \\
\hline
\end{tabular}

Data are expressed as median and percentile (interquartile range 25-75) as the nonparametric distribution UNGAL. The Shapiro-Wilk normality test was performed. AKI: acute kidney injury; RRT: renal replacement therapy

Variables associated with the need for RRT in the univariate analysis were included in the multivariable logistic model: duration of anesthesia, SOFA score at ICU admission, urine output and fluid balance within $24 \mathrm{~h}$ of surgery (Table 3 ). In the model including UNGAL, the biomarkerwas the most powerful predictor for RRT need.

\section{Performance of NGAL to predict mortality in the perioperative LT period}

The 60 -day mortality rate was $21 \%$ (21); 03 (14.3\%) in no-AKI/mild-AKI group and 18 (85.7\%) in the severeAKI group $(P=0.005)$. The main causes of death were septic shock 07 (33.3\%), primary graft dysfunction 03 (14.3\%) and hemorrhagic shock 03 (14.3\%). The best time point for using PNGAL levels to predict mortality was at $18 \mathrm{~h}$ after surgery, with an AUC of 0.76 (CI95\% 0.60-0.92) for levels higher than $483 \mathrm{ng} / \mathrm{ml}$. UNGAL was significantly higher in non-survivors even before surgery, in the pre-operative period. The median was $33 \mathrm{ng} / \mathrm{dl}$ in survivors versus $220 \mathrm{ng} / \mathrm{dl}$ in non-survivors $(P=0.002)$. Six hours after $\mathrm{LT}$, a value higher than $242.06 \mathrm{ng} / \mathrm{ml}$ had an AUC of 0.81 (CI 0.65-0.97) for predicting mortality with sensitivity $86 \%$ and specificity $64 \%$ (Table 2 and Fig. 2). In the multivariable analysis, duration of anesthesia, SOFA on ICU admission and MELD were included in the model. The only independent predictor of mortality, in analyses including PNGAL or UNGAL, was the SOFA score (Table 3). 

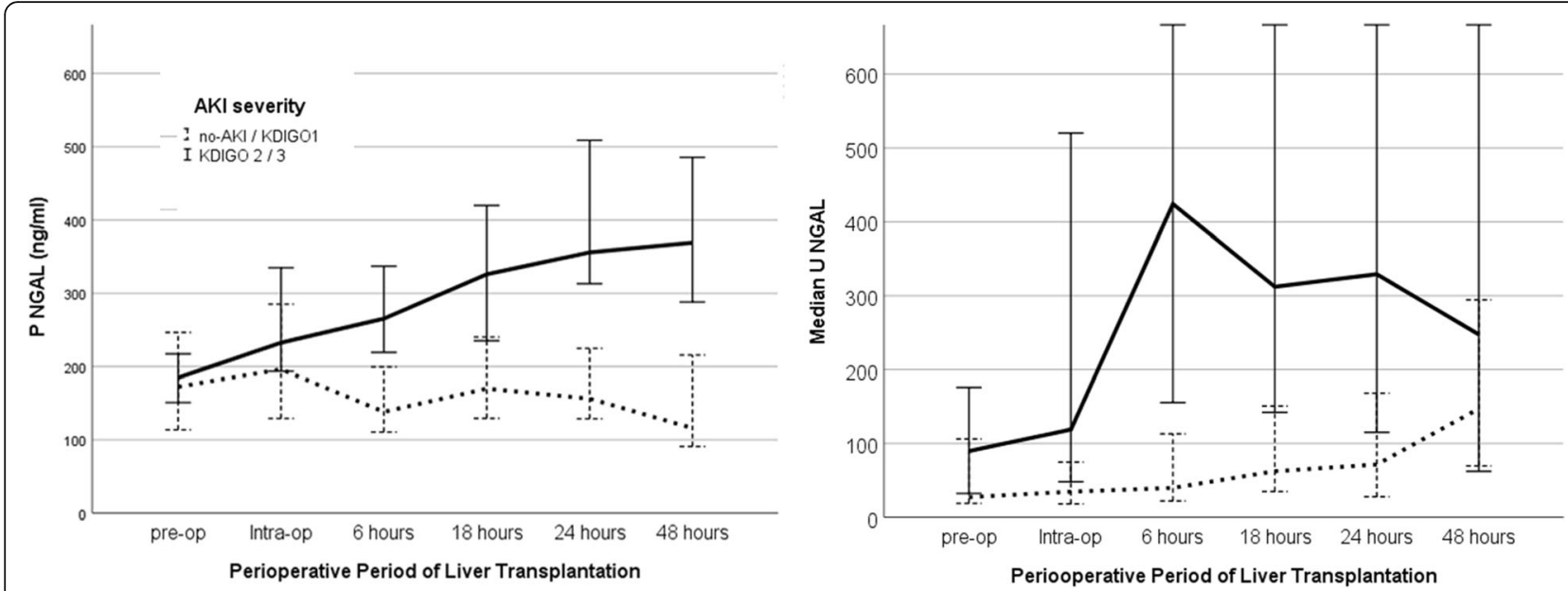

Fig. 3 Median of the PNGAL and UNGAL in the perioperative liver transplant in no-AKI/ mild- AKI and severe-AKI groups

\section{Discussion}

Acute kidney injury in the post-operative period of LT is associated with several short- and long-term complications. The short-term effects of AKI includs disturbances in acid-base and electrolyte homeostasis, azotemia, volume overload, increasingd duration of mechanical ventilation and ICU stay. The long-term effects are reflected in the higher rates of CKD development and decreased patient and graft survival.
The importance of early diagnosis of AKI is particularly significant in patients with chronic liver disease, for whom serum creatinine is known to be a worse marker of kidney function. Based on ambulatory values, $11 \%$ of our patients in the waiting list for liver transplant were CKD stage 3 or 4 . It is likely that eGFR values in these patients are overestimating renal function, and an even higher proportion of patients had a severe degree of dysfunction. The complications of liver disease in these

Table 3 Multivariable logistic models with PNGAL and UNGAL for AKI, need for RRT and mortality

\begin{tabular}{|c|c|c|c|c|}
\hline VARIABLES & model pngal OR (IC 95\%) & $P$ & model ungal OR (IC 95\%) & $p$ \\
\hline \multicolumn{5}{|l|}{ AKI } \\
\hline Age (years) & $0.9(0.92-1.02)$ & 0.25 & $0.98(0.93-1.02)$ & 0.4 \\
\hline duration anesthesia (hours) & $1.54(1.08-2.20)$ & 0.16 & $1.61(1.14-2.27)$ & 0.007 \\
\hline Urine output first day after LT (ml) & $0.99(0.99-1.00)$ & 0.28 & $26.5(5)$ & 0.65 \\
\hline Fluid balance first day after $L T(\mathrm{ml})$ & $1.00(1.00-1.00)$ & 0.07 & $0.99(0.99-1.00)$ & 0.12 \\
\hline sofa & $1.12(0.91-1.38)$ & 0.27 & $16(12-22)$ & 0.01 \\
\hline ngal (ng/ml) & $4.72(0.87-25.39)$ & 0.07 & $7.87(1.2-39.70)$ & 0.02 \\
\hline \multicolumn{5}{|l|}{ need rrt } \\
\hline duration anesthesia (hours) & $1.11(0.79-1.56)$ & 0.52 & $1.11(0.75-1.69)$ & 0.58 \\
\hline Urine output first day after LT (ml) & $0.99(0.99-0.99)$ & $<0.001$ & $0.99(0.99-0.99)$ & 0.001 \\
\hline Fluid balance first day after $L T(\mathrm{ml})$ & $1.00(1.00-1.00)$ & 0.22 & $1.00(1.00-1.00)$ & 0.36 \\
\hline sofa & $1.48(1.13-1.94)$ & 0.004 & $1.49(1.10-2.02)$ & 0.009 \\
\hline ngal (ng/ml) & $2.74(1.35-5.52)$ & 0.005 & $35.28(2.8-444)$ & 0.006 \\
\hline \multicolumn{5}{|l|}{ MORTALITY } \\
\hline duration anesthesia (hours) & $1.48(1.08-2.09)$ & 0.01 & $21(64 \%)$ & 0.43 \\
\hline MELD & $1.00(0.88-1.13)$ & 0.95 & $14(50 \%)$ & 0.26 \\
\hline sofa & $1.72(1.23-2.42)$ & 0.002 & $1.62(1.16-2.26)$ & 0.004 \\
\hline ngal (ng/ml) & $2.20(0.33-15)$ & 0.41 & $6.10(0.66-56)$ & 0.11 \\
\hline
\end{tabular}

AKI (acute kidney injury), OR (odds ratio), MELD (model for end-stage liver disease), SOFA (Sequential Organ Failure Assessment), RRT (renal replacement therapy) 
patients predispose them to oscillations of serum creatinine, and frequent episodes of AKI. Before surgery, 34 patients in our cohort already had an elevation in $\mathrm{sCr}$ higher than $0.3 \mathrm{mg} / \mathrm{dl}$ from the baseline ambulatory values and were considered as having pre-operative AKI. In these patients, NGAL levels were considerably higher than in patients without pre-operative AKI and continued to increase during intra-operative assessment. The high levels of NGAL at the initial pre-operative assessment were associated with the degree of injury in the post-operative period.

The potential of early biomarkers of kidney injury, such as NGAL, to detect AKI earlier has been shown in previous studies [23, 24, 29]. Nieman et al. [22], found that a PNGAL level higher than $139 \mathrm{ng} / \mathrm{ml}$ after portal reperfusion was a good predictor of AKI development; AUC of 0.79. In our study, UNGAL values after portal reperfusion and $6 \mathrm{~h}$ after surgery were good predictors of AKI within 7 days, with AUC of 0.67 and 0.76. However, NGAL is not specifically related to kidney injury; it is produced in many different tissues. Consequently, marked elevation can also occur in acute as well as chronic systemic inflammation. As such, the cut-off for determining kidney injury in this specific population with a higher degree of inflammation may differ to that applied in critically ill patients. In the meta-analysis by Haase et al. [30], which included 19 studies and 2538 patients, 487 (19.2\%) developed AKI and NGAL was a good predictor of AKI with an odds ratio (OR) of 18.6 and an AUC of 0.81. Analyzing different populations, the best cut-off value found in those studies varied within the $100-270 \mathrm{ng} / \mathrm{ml}$ range, and the authors proposed a value of $150 \mathrm{ng} / \mathrm{ml}$ for diagnosing AKI [30]. In our cohort, despite the high severity of illness, our cutoff levels for AKI at $198 \mathrm{ng} / \mathrm{ml}$ for PNGAL and $136 \mathrm{ng} /$ $\mathrm{ml}$ for UNGAL were within the range proposed in the meta-analysis.

We found UNGAL to be a better predictor of AKI development than PNGAL. Similar findings were reported by Baron-Stefaniak et al. [31]. Although not adjusting for other covariates, the authors found UNGAL to be a better predictor of AKI severity than PNGAL. In our study, UNGAL was the most powerful independent predictor of AKI, with an OR of 7.87.

A few studies [32] have compared the timing of AKI diagnosis by early biomarkers in the perioperative of LT. In a prospective study of 92 liver transplant recipients, Wagener et al. [24] demonstrated that the urinaryNGAL/urinary-creatinine ratio $3 \mathrm{~h}$ after liver transplant was a reliable marker of post-LT AKI and provided a diagnostic benefit of approximately two days compared to serum creatinine. We evaluated the timing of AKI diagnosis by the gold standard, $\mathrm{sCr}$, and our cut-off values for UNGAL and PNGAL. Despite the high frequency of early AKI in our study, the presence of multiple risk factors in our population, including possibly ongoing kidney injury in the pre-operative period, NGAL was able to anticipate AKI detection and prediction of its severity by one day.

It is possible that NGAL levels, used in association with $\mathrm{sCr}$, could contribute to the evaluation of the likelihood of early recovery, helping to distinguish functional from established structural damage. Our findings also showed UNGAL to be a good predictor of need for RRT and mortality. UNGAL was an independent predictor of need for dialysis, with a sensitivity of $86 \%$ and specificity of $80 \%$ (AUC 0.85). This finding suggests that early peak levels can be useful in deciding on early RRT initiation and influencing RRT method, e.g., continuous therapy in high-risk patients.

The high mortality rate in our cohort can be partially explained by the overall severity of patients, their older age and presence of comorbidities (hypertension, diabetes mellitus), higher MELD [22, 24, 33], and prolonged warm ischemia time. Several studies have shown an association between pre-LT MELD score and post-LT AKI [34-37]. Patients with high MELD scores are found to have a significantly increased risk of post-LT AKI and the development of CKD and ESDR [38]. Each minute of warm ischemia time is associated with an increase of $8-9 \%$ in the risk of non-recoverable renal function after LT $[39,40]$. Bleeding and need for transfusion were frequent in our cohort and also associated with the increase in the mortality rate [41]. We found that UNGAL levels $6 \mathrm{~h}$ after liver transplant were a good predictor of mortality, with values higher than $483 \mathrm{ng} / \mathrm{ml}$ in 18 out of 21 of non-survivors (85\%). Predicting patients with higher risk for mortality in early stages of liver transplant can help physicians to decide on appropriate management and possibly lead to improved outcomes.

Despite not being a multicentre study, this is the largest cohort for evaluating a biomarker perioperative of liver transplant. In this analysis, we used serum creatinine as a sole performance comparator for diagnosis of AKI, not applying urine output criteria. It is possible that some patients would have an earlier diagnosis based on urine volume and the delay in AKI diagnosis by KDIGO system decreased. Our incidence of AKI was high: 85\% and 59 were AKI stage 2/3. Previous studies applying the RIFLE criteria have not considered $0,3 \mathrm{mg} / \mathrm{dl}$ serum creatinine criteria to define AKI [22, 24, 29, 32]. In our study, we applied the serum creatinine KDIGO definition as stated $-0.3 \mathrm{mg} / \mathrm{dl}$ within $48 \mathrm{~h}$ and $50 \%$ within 7 days - in contrast to most studies, which limited the time frame for diagnosis to $48 \mathrm{~h}[23,31,42]$. Thus, in our analysis, similar to other analyses $[8,31]$, we have grouped no AKI with mild-AKI. Larger cohorts including less severely ill patients should be evaluated to 
confirm NGAL predictive ability to determine AKI severity, need for dialysis and mortality.

\section{Conclusions}

NGAL is a promising biomarker for predicting AKI severity in patients undergoing liver transplant. The pattern of plasma- and urinary-NGAL elevation in the period perioperative of liver transplant allows earlier AKI diagnosis than KIDGO criteria based on serum creatinine. UNGAL was an independent predictor of AKI development and need for dialysis. Future studies should evaluate whether the clinical use of these biomarkers could improve patient outcomes.

\section{Abbreviations \\ AKI: Acute kidney injury; AUC: Area under the curve; CKD: Chronic kidney disease; eGRF: Estimated glomerular filtration rate; EMR: Electronic medical records; EPI: Epidemiology Collaboration; ESLD: End-stage liver disease; ESRD: End-stage renal disease; ICU: Intensive care unit; INR: International normalised ratio; KDIGO: Kidney Disease: Improving Global Outcomes; LT: Liver transplant; MELD: Model for end-stage liver disease; NASH: Non- alcoholic steatohepatitis; NGAL: Neutrophil gelatinase-associated lipocalin; PNGAL: Plasma NGAL; PPV: Positive predictive value; ROC: Receiver operating characteristic; rpm: Rotation per minute; RRT: Replacement therapy; sCr: Serum creatinine; SD: Standard deviation; SOFA: Sequential Organ Failure; SPSS: Statistical Package for Social Sciences; UNGAL: Urinary NGAL}

\section{Acknowledgements}

The authors thank Fatima Liborio, data analyst at the Urology Division of HCFMUSP, and Labtest for processing the samples and performing the research laboratory assays. Portions of this study have been presented in abstract form on posters at ASN Kidney Week 2014 and 2015.

\section{Authors' contributions}

Authors CL, LBPH and EM provided the conceptualization of ideas and the evolution of overarching research goals and aims. Authors $\mathrm{CL}$ and $\mathrm{EM}$ were responsible for data curation, management activities, maintaining research data, formal analysis, application of statistics, acquisition of financial support for the project leading to this publication, design of methodology, administrative management and coordinating the planning and execution of the research activity. All authors $C L, L B P H, P D V M, ~ L M M, ~ L P F C, ~ L A C D ' A$ and $\mathrm{EM}$, conducted a research and investigation process; collection of data/ evidence and resources; provision of study materials, reagents, patients, laboratory samples and other analytical tools and prepared, created and wrote the original draft and gave final approval of the version to be published. Author EM supervised and had leadership responsibility for the planning and execution of the research activity, including mentorship external to the core team.

\section{Funding}

This work was supported by the São Paulo Research Foundation (FAPESP) process number 2013/12710-2. The funds are part of a government incentive for research, and the money was used in the purchase and analysis of the biomarker NGAL. The first author received a scholarship from the Brazilian National Council of Scientific and Technological Development (CNPQ) used to collection of samples, analysis and writing the manuscript.

\section{Availability of data and materials}

The anonymized dataset is held by the corresponding author and data may be made available in part for secondary analysis by third parties. Access will be granted upon reasonable request.

\section{Ethics approval and consent to participate}

All patients signed an informed consent according to the protocol approved by the Research Ethics Committee, Hospital das Clinicas, Faculty of Medicine, University of São Paulo with number 266581 and Brazil platform CAAE
06636513400000068. The protocol is available on https://clinicaltrials.gov with identifier NCT02095431.

\section{Consent for publication}

Not applicable.

\section{Competing interests}

The authors declare that there is no conflict of interest regarding the publication of this paper.

\section{Author details}

${ }^{1}$ Department of Internal Medicine, Nephrology Division, University of Sao Paulo, Present Address: 419 Av. Dr Enéas de Carvalho Aguiar, third floor room 340, 05403-000, Cerqueira Cesar, São Paulo, Brazil. ${ }^{2}$ Department of Medical Surgical Nursing, University of Sao Paulo Nursing School, Sao Paulo, Brazil. ${ }^{3}$ Department of Gastrointestinal Surgery, Clinical Surgery Division, University of Sao Paulo, Sao Paulo, Brazil. ${ }^{4}$ Present Address: La Jolla, San Diego, USA. ${ }^{5}$ Department of Biology, Biochemistry Division, Federal University of Minas Gerais, Belo Horizont, Brazil. ' Department of Anaesthesiology, Clinical Surgery Division, University of Sao Paulo, Sao Paulo, Brazil. ${ }^{7}$ Department of Medicine, Nephrology Division, University of California San Diego, San Diego, USA.

Received: 20 December 2018 Accepted: 26 September 2019

Published online: 15 October 2019

\section{References}

1. Hilmi A, Damian D, Al-Khafaji A, Planinsic R, Boucek C, Sakai T, et al. Acute kidney injury following orthotopic liver transplantation: incidence, risk factors, and effects on patient and graft outcomes. Br J Anaesth. 2015;10:18. https://doi.org/10.1093/bja/aeu556.

2. Barri YM, Sanchez EQ, Jennings LW, Melton LB, Hays S, Levy MF, et al.. Acute kidney injury following liver transplantation: definition and outcome. Liver Transpl. 2009;15:475-483. https://doi.org/10.1002/lt.21682. PMID: 19399734

3. Karapanagiotou A, Kydona C, Dimitriadis C, Sgourou K, Giasnetsova T, Fouzas I, et al. Acute kidney injury after orthotopic liver transplantation. Transplant Proc. 2012;44:2727-9. https://doi.org/10.1016/j.transproceed. 2012.09.096

4. Feldkamp T, Bienholz A, Krilben A. Urinary neutrophil gelatinase- associated lipocalin (NGAL) for the detection of acute kidney injury after orthotopic liver transplantation. Nephol Dial Transplant. 2011;26:1456-8. https://doi.org/ $10.1093 / \mathrm{ndt} / \mathrm{gfr} 146$

5. Tinti F, Umbro I, Mecule A, Rossi M, Merli M, Nofroni I, et al. RIFLE criteria and hepatic function in the assessment of acute renal failure in liver transplantation. Transplant Proc. 2010;42:1233-6. https://doi.org/10.1016/j. transproceed.2010.03.128.

6. Park MH, Shim HS, Kim WH, Kim HJ, Kim DJ, Lee SH, et al. Clinical risk scoring models for prediction of acute kidney injury after living donor liver transplantation: a retrospective observational study. PLoS One. 2015;10: e0136230. https://doi.org/10.1371/journal.pone.0136230.

7. Weber ML, Ibrahim HN, Lake JR. Renal dysfunction in liver transplant recipients: evaluation of the critical issues. Liver Transpl. 2012;18:1290-301. https://doi.org/10.1002/lt.23522.

8. Barreto $A G$, Daher EF, Silva Junior $G B$, Garcia JH, Magalhães $C B$, et al. Risk factors for acute kidney injury and 30-day mortality after liver transplantation. Ann Hepatol 2015;14:688-694. PMID: 26256897.

9. Yalavarthy $\mathrm{R}$, Edelstein $\mathrm{CL}$, Teitelbaum I. Acute renal failure and chronic kidney disease following liver transplantation. Hemodial Int 2007;11:7. doi: https://doi.org/10.1111/j.1542-4758.2007.00223.x. PMID: 17897111.

10. Afonso RC, Hidalgo R, Zurstrassen MPVC, Fonseca LEP, Pandullo L, Rezende $M B$, et al. Impact of renal failure on liver transplantation survival. Transpl Proc. 2008:40:808-10. https://doi.org/10.1016/.transproceed.2008.02.062.

11. Gonwa TA, Mai ML, Melton LB, Hays SR, Goldstein RM, Levy MF,.et al. Renal replacement therapy and orthotopic liver transplantation: the role of continuous veno-venous hemodialysis. Transplantation 2001;71:1424-1428. PMID: 11391230

12. Mehta RL, Kellum JA, Shah SV, Molitoris BA, Ronco C, Warnock DG, et al. Acute Kidney Injury Network: report of an initiative to improve outcomes in acute kidney injury. Crit. Care. 2007;11:1-8. https://doi.org/10.1186/cc5713. 
13. Ojo AO, Held PJ, Port FK, Wolfe RA, Leichtman AB, Young EW, et al. Chronic renal failure after transplantation of a nonrenal organ. N Engl J Med 2003; 349:931-940. doi: https://doi.org/10.1111/ajt.13314. PMID: 12954741.

14. Goldberg DS, Ruebner RL, Abt PL. The risk of end-stage renal disease among living donor liver transplant recipients in the United States. Am J Transplant 2015;15:2732-2738. doi: https://doi.org/10.1111/ajt.13314. PMID: 25969133.

15. Nickolas TL, O'Rourke MJ, Yang J, Sise ME, Canetta PA, Barasch N, et al. Sensitivity and specificity of a single emergency department measurement of urinary neutrophil gelatinase-associated lipocalin for diagnosing acute kidney injury. Ann Intern Med 2008;148:810-819. PMID: 18519927.

16. Slack A, Yeoman A, Wendon J. Renal dysfunction in chronic liver disease. Crit Care. 2010;14(2):214.

17. Beben T, RifkiAdv DE. Chronic kidney dis. GFR estimating equations and liver disease. Adv Chronic Kidney Dis. 2015;22(5):337-42. https://doi.org/10. 1053/j.ackd.2015.05.003.

18. Malyszko J. Biomarker of acute kidney injury indifferent clinical settings a time to change the paradigm? Kidney Blood Press Res 2010;33:368-382. doi: https://doi.org/10.1159/000319505. PMID: 20924195.

19. Di Somma S, Magrini L, Berardinis B, Marino R, Ferri E, Moscatelli P,et al. Additive value of blood neutrophil gelatinase associated lipocalin to clinical judgement in acute kidney injury diagnosis and mortality prediction in patients hospitalized from the emergency department. Crit Care 2013; 17(29):1-13. doi: https://doi.org/10.1186/cc12510. PMID: 23402494.

20. Constantin JM, Futier E, Perbet S, Roszyk L, Lautrette A, Gillart T, et al. Plasma neutrophil gelatinase-associated lipocalin is an early marker of acute kidney injury in adult critically ill patients: a prospective study. J Crit Care. 2010 Mar;25(1):176.e1-176.e6. doi: https://doi.org/10.1016/j.jcrc.2009.05.010. PMID: 19781900.

21. Zhou F, Luo Q, Wang L, Han L. Diagnostic value of neutrophil gelatinaseassociated lipocalin for early diagnosis of cardiac surgery-associated acute kidney injury: a meta-analysis. Eur J Cardiothorac Surg 2016;49(3):746-755. doi: https://doi.org/10.1093/ejcts/ezv199. PMID: 26094017.

22. Niemann CU, Walia A, Waldman J, Davio M, Roberts JP, Hirose R, et al. Acute kidney injury during liver transplantation as determined by neutrophil GelatinaseAssociated Lipocalin. Liver Transpl 2009;15:1852-1860. doi: https:// doi.org/10.1002/lt.21938. PMID: 19938135

23. Portal AJ, McPhail MJW, Bruce M, Coltart I, Slack A, Sherwood R, et al. Neutrophil Gelatinase - associated Lipocalin predicts acute kidney injury in patients undergoing liver transplantation. Liver Transplantation 2010;16: 1257-1266. doi: https://doi.org/10.1002/lt.22158. PMID: 21031541.

24. Wagener G, Minhaz M, Mattis FA, Kim M, Emond JC, Lee HT.. Urinary neutrophil gelatinase-associated lipocalin as a marker of acute kidney injury after orthotopic liver transplantation. Nephrol Dial Transplant 2011;26:17171723. doi: https://doi.org/10.1093/ndt/gfq770. PMID: 21257679.

25. Robertson FP, Yeung AC, Male V, Rahman S, Mallett S, Fuller BJ, Davidson BR. Urinary neutrophil Gelatinase associated Lipocalins (NGALs) predict acute kidney injury post liver transplant. HPB. 2018:1-9. https://doi.org/10. 1016/j.hpb.2018.09.017

26. Cheng CW, Chen YC, Chang CH, Yu HP, Lin CC, Yang MW, et al. The ratio of plasma neutrophil gelatinase-associated lipocalin predicts acute kidney injury in patients undergoing liver transplantation. Transplant Proc $2012 \mathrm{Apr}$; 44(3):776-779. doi:https://doi.org/10.1016/j.transproceed.2012.01.068. PMID: 22483493

27. Brasil. Ministério da Saúde. Portaria n².600, de 21 de Outubro de 2009. Aprova o Regulamento Técnico do Sistema Nacional de Transplantes. Available from: http://bvsms.saude.gov.br/bvs/saudelegis/gm/2009/prt26 $0021 \quad 10$ 2009.html Accessed in 2017 (Set 18).

28. Kidney Disease Improving Global Outcomes (KDIGO) Acute Kidney Injury Work Group. KDIGO Clinical Practice Guideline for Acute Kidney Injury. Kidney Inter., Suppl. 2012; 2: 1-138.

29. Sirota JC, Walcher A, Faubel S, Jani A, MCFann K, Devarajan P, et al. Urine IL$18, N G A L, I L-8$ and serum IL-8 are biomarkers of acute kidney injury following liver transplantation. BMC Nephrol 2013 Jan 17;14:17. doi: https:// doi.org/10.1186/1471-2369-14-17. PMID: 23327592

30. Haase M, Bellomo R, Devarajan P, Schlattmann P, Haase-Fielitz A. NGAL meta-analysis Investigator Group. Accuracy of neutrophil gelatinaseassociated lipocalin (NGAL) in diagnosis and prognosis in acute kidney injury: a systematic review and metaanalysis. Am J Kidney Dis 2009;54:10121024. doi: https://doi.org/10.1053/j.ajkd.2009.07.020. PMID: 19850388.

31. Baron-Stefaniak J, Schiefer J, Miller EJ, Berlakovich GA, BaronDM, Faybik P. comparison of macrophage migration inhibitory factor and neutrophil gelatinaseassociated lipocalin-2 to predict acute kidney injury after liver transplantation: an observational pilot study. PLoS One 2017 Aug 15;12(8):114. doi: https://doi.org/10.1371/journal.pone.0183162. PMID: 28813470.

32. Jeong T-D, Kim S, Lee W, Song G-W, Kim Y-K, Chun S, et al. Neutrophil gelatinase-associated lipocalin as an early biomarker of acute kidney injury in liver transplantation. Clin Transplant 2012 Sep-Oct;26(5):775-781. doi: https://doi.org/10.1111/j.1399-0012.2012.01610.x PMID: 22404749.

33. Charlton MR. Improving long -term outcomes after liver transplantation. Clin Liver Dis 2014 Aug;18(3):717-730. doi: https://doi.org/10.1016/j.cld.2014.05. 011. PMID: 25017085.

34. Saxena V, Lai JC. Renal Failure and Liver Allocation: Current Practices and Potential Improvements. Adv Chronic Kidney Dis. 2015;Sep.22(5):391-398. doi:https://doi.org/10.1053/j.ackd.2015.05.002. PMID: 26311601.

35. Schlegel A, Linecker M, Kron P, Gyori G, De Oliveira ML, Mullhaupt B, et al. Risk assessment in high- and low-MELD liver transplantation. Am J Transpl 2016 Apr;17(4):1050-1063. doi: https://doi.org/10.1111/ajt.14065. PMID: 27676319.

36. Schmitt TM, Kumer SC, Al-Osaimi A, Shah N, Argo CK, Berg C, et al. Combined liver-kidney and liver transplantation in patients with renal failure outcomes in the MELD era. Transpl Int 2009 Sep;22(9):876-883. doi: https:// doi.org/10.1111/j.1432-2277.2009.00887.x. PMID: 19413580.

37. Parajuli S, Foley D, Djamali A, Mandelbrot D. Renal function and transplantation in liver disease transplantation. Transplantation. 2015 Sep; 99(9):1756-1764. doi: https://doi.org/10.1097/TP.0000000000000820. PMID: 26308413.

38. Chang Y, Gallon L, Jay C, Shetty K, Bing-ho, Levitsky J, et al. comparative effectiveness of liver transplant strategies for end-stage liver disease patients on renal replacement therapy. Liver Transpl 2014 Sep;20(9):10341044. doi:https://doi.org/10.1002/lt.23899. PMID: 24777647.

39. Laskey HL, Schomaker N, Hung KW, Asrani SK, Jennings L, Nydam TL,et al. Predicting renal recovery after liver transplant with severe pretransplant subacute kidney injury: the impact of warm ischemic time. Liver Transpl 2016 Aug;22(8):1085-1091. doi: https://doi.org/10.1002/lt.24488. Epub 2016 Jul 12. PMID: 27302834.

40. Maggi U, Fornoni G, Centonze L, Melada E, Conte G, Rossi G. Ischemia time and liver transplantation, today. Transplant Proc 2014 Sep;46(7):2295-2299. doi: https://doi.org/10.1016/j.transproceed.2014.07.040. PMID: 25242773.

41. Reichert B, Kaltenborn A, Becker T, Schiffer M, Klempnauer J, Schrem H. Massive blood transfusion after the first cut in liver transplantation predicts renal outcome and survival. Langenbeck's Arch Surg 2014 Apr;399(4):429440. doi: https://doi.org/10.1007/s00423-014-1181-y. PMID: 24682384

42. Dedeoglu B, Geus HRH, Fortrie G, Betjes MGH. Novel biomarkers for the prediction of acute kidney injury in patients undergoing liver transplantation. Biomarkers Med 2013 Dec;7(6):947-957. doi: https://doi.org/ 10.2217/bmm.13.91. PMID: 24266830

\section{Publisher's Note}

Springer Nature remains neutral with regard to jurisdictional claims in published maps and institutional affiliations.

Ready to submit your research? Choose BMC and benefit from:

- fast, convenient online submission

- thorough peer review by experienced researchers in your field

- rapid publication on acceptance

- support for research data, including large and complex data types

- gold Open Access which fosters wider collaboration and increased citations

- maximum visibility for your research: over $100 \mathrm{M}$ website views per year

At $\mathrm{BMC}$, research is always in progress.

Learn more biomedcentral.com/submissions 